\title{
A complex system for the production of pathogen-free grapevine propagating material
}

\author{
Bisztray, Gy. D. ${ }^{1 *}$, Lázár, J. ${ }^{2}$, Szegedi, E. ${ }^{2}$, Varga, G. ${ }^{2}$, Nagy, B. ${ }^{1}$ \& \\ Hajdu, E. 2* \\ ${ }^{1}$ Corvinus University of Budapest, Institute of Viticulture and Oenology, Department of Viticulture \\ 1118 Budapest, Villányi út 29-43, Hungary \\ ${ }^{2}$ Corvinus University of Budapest, Institute of Viticulture and Oenology, Research Station Kecskemét \\ 6001 Kecskemét, P.O.Box 25, Hungary \\ *author for correspondence, e-mail: gyorgy.bisztray@uni-corvinus.hu; edit.hajdu@uni-corvinus.hu
}

\begin{abstract}
Summary: The use of pathogen-free planting stock for new vineyard establishment is a key component in the maintenance and expansion of vine and quality table grape production. The success of the necessary changes in the structure of the grape industry is forced by the globalization process, the climate change, the rediscovery of autochton varieties as well as breeding of new tolerant and resistant varieties. The renewal of vineyards largely depend on the availability of planting stocks. Serbia and Hungary found a common interest in establishing pathogen-free stock materials from newly breed resistant varieties and clonal selections of varieties which are traditional in the SerbianHungarian border area. During a cross-border cooperation program a complex system for the production of pathogen-free grapevine propagating material was established. Using heat therapy, in vitro shoot tip culture and traditional and molecular diagnostic techniques new pathogen-free stock materials were established from 26 varieties. They have been or will be tested for the presence of most important grapevine viruses, phytoplasmas, as well as bacterial and fungal pathogens. The complex system applying green grafting for indexing on grapevine indicators can shorten the duration of the procedure from 4 years to two-three years.
\end{abstract}

Keywords: grape propagation, heat therapy, micropropagation, pathogen-free grapevines, virus indexing

\section{Introduction}

During the recent decades in Central Europe, especially in Hungary the grapevine producing area as well as the area of certified vineyards was shrunken dramatically. The number of virus-free basic stocks and certified propagation blocks dropped back. At the same time the structural changes in the grape industry accelerated. In some countries there is a shortfall in desirable planting stock. It is especially true in Hungary where regulation for the production of pathogenfree grapevine materials (Lehoczky et al., 1992, Lázár 1996; Neszmélyi et al., 1996) is stricter than the EU regulation (Martelli 1992; Martelli \& Boudon-Padieu 2006; OEEP/EPPO 2008) while the system of pathogen elimination and the certification process is a very slow process (Lázár 1996, Lázár et al. 2002). The domestic nursery industry have to respond to demands for scarce varietal and clonal selections, or new rootstocks, with techniques that allow the rapid expansion of propagating stock and a solid pathogen-free quality. In addition to the demand for varietal grape materials from nurseries, the issue of clonal selection especially from autochthon varieties has become increasingly important. There is great interest in techniques that speed up the process by which pathogen-free materials can be produced.

The pathological status of the vineyards in Hungary and Serbia shows that the different viruses, phytoplasmas and agrobacteria are common, and some fungal diseases are also present in vineyards. In Hungary the detection of virus and virus-like diseases of grapevine was started in 1960's (Lehoczky \& Reichart 1968, Lehoczky \& Tasnády 1971) and the regular virological screening was introduced in 1972. Until now 17 virus and virus-like diseases have been detected (Lehoczky \& Burgyán 1986, Lázár 1996, Kölber et al. 1997, Lázár et al. 2002, Lázár \& Bisztray 2011). During a recent survey (Cseh et al. 2011) based on symptoms and serological tests 90 out of the 277 samples were virus positive. The presence of the most important viruses such as Grapevine fanleaf virus (GFLV), Arabis mosaic virus (ArMV), Tomato black ring virus (TBRV), Grapevine chrome mosaic virus (GCMV), Grapevine leafroll-associated virus 1-3 (GLRaV 1-3) and Grapevine fleck virus (GFkV) as well as Alfalfa Mosaic virus (AMV) were found in single or mixed infections. The occurrence of GLRaV-1 and GLRaV-3 has increased.

In Serbia the evaluation of the sanitary status of national grapevine germplasm and variety collections is an important part of a program to help grapevine industries (Kuzmanovic et al. 2003, Starovi et al. 2007). Recently 4 variety collections and 13 Serbian autochthonous varieties subjected to clonal selection have been screened for viruses by ELISA and RTPCR (Mandičet al., 2009). These data confirmed the previous results on the sanitary status of Serbian viticulture industry and the differential virus distribution according to climate and latitude. GFkV was the most common virus followed by 
leafroll agents (GLRaV-1, GLRaV-3 and GLRaV-2), while nepoviruses (GFLV and ArMV) were rarely detected. The presence of 9 viruses including GVA and GVB were shown and a relatively high number of single infections, as compared with multiple infections, were detected.

The use of pathogen-free planting stock in new vineyard establishment is a key component in the maintenance and expansion of vine and quality table grape production. Certification programs for the production of virus-free propagating material of grapevine have been started in Hungary and Serbia. The sanitary status of grape propagating material and the certification processes of pathogen-free materials are controlled by the State (Neszmélyi et al. 1996, Mandi et al. 2009). According to the EU regulation (Martelli 1992, Martelli \& Boudon-Padieu 2006, OEEP/EPPO 2008) grapevine propagating materials should be tested for five viruses (GFLV, ArMV, GLRaV1-3 and GFkV) while in Hungary the certification process includes the testing of more than nine viral, two phytoplasmal, as well as additional bacterial and fungal pathogens (Lázár 1996, Lázár et al. 2002, Neszmélyi 1996). Therefore the certification process used in Hungary is slower and less economical as compared to other EU countries. Recently testing for the presence/ absence of more than five viruses proved to be important, therefore it has been advised in EU to extend the number of viruses to be tested (Martelli 2009).

In the traditional procedure to certify virus-free materials indexing on woody indicators is the bottleneck since it takes at least 2 years in the regular virus testing procedure. This way the whole procedure to release certified virus and pathogen-free material lasts 3 to four years (Lázár 1996, Lázár et al. 2002). In some countries the indexing on woody indicators is accelerated by the use of in vitro micrografting or in vivo green grafting techniques. At present in Hungary the indexing on woody indicators for three years is commonly used (Lázár 1996, Lázár et al. 2002, Lehoczky et al. 1992, Neszmélyi et al. 1996).

Serbia and Hungary found a common interest in establishing pathogen-free stock materials from newly breed resistant varieties and clonal selections from traditional varieties in the Serbian-Hungarian border area. During a cross border cooperation program we started to establish a complex system for the production of pathogen-free grapevine propagating material. To this end hot water treatment, heat therapy, in vitro shoot tip cultures, traditional and molecular screening techniques were combined to establish new pathogen-free stock materials from 26 varieties. Our studies included detection of the most important grapevine viruses, phytoplasmas, bacterial and fungal pathogens.

\section{Material and method}

Woody canes of the grapevine varieties were collected from the collection of the Research Station Kecskemét, Institute of Viticulture and Oenology, Corvinus University of Budapest and at the Research Station of the University of
Novi Sad, Serbia (Table 1.). The sanitary status was investigated at Kecskemét. The Hungarian material has previously been tested for viruses and virus-like diseases symptomatologically as well as by indexing on woody grapevine indicators (Table 2.) (Figure 1.) and ELISA (Lázár 1996, Lázár et al. 2002). The majority of the Hungarian material was tested for varietal identity by RAPD (Bisztray et al. 2003) and by microsatellite markers (Bisztray et al. 2005, Bodor et al. 2008, Varga et al. 2008). In this study the identity of 'Furmint' and 'Kadarka' clones were investigated by the method described earlier (Bisztray et al. 2005).

Table 1. The list of grapevine varieties (clones) involved in the pathogen-freeing program

\begin{tabular}{|c|l|l|}
\hline No. & Hungarian varieties, clones & Serbian varieties, clones \\
\hline 1. & Arany sárfehér Kt.2 & Bačka \\
\hline 2. & Bianca E.66 & Karmen \\
\hline 3. & Ezerjó Kt.12 & Lasta \\
\hline 4. & Fanny & Morava \\
\hline 5. & Furmint T.85 & Muscat de Hamburg B8 \\
\hline 6. & Generosa Kt.21 & Muscat de Hamburg B9 \\
\hline 7. & Irsai Olivér K.11 & Neoplanta \\
\hline 8. & Kadarka Kt.3 & Pannonia \\
\hline 9. & Kékfrankos Kt.1 & Petra \\
\hline 10. & Kövidinka K.8 & Probus \\
\hline 11. & Melinda & Welshriesling RI-SK 54-10 \\
\hline 12. & Ottonel muskotály Kt.16 & Welshriesling RI-SK 61-6 \\
\hline 13. & Pannónia kincse K.56 & \\
\hline 14. & Sauvignon blanc Kt.10 & \\
\hline
\end{tabular}

Table 2. Indicator varieties used for the identification of the main virus and virus-like diseases of the grapevine

\begin{tabular}{|l|l|}
\hline \multicolumn{1}{|c|}{ Indicator varieties } & \multicolumn{1}{c|}{ Viruses } \\
\hline Siegfriedrebe (FS4 201-39) & Infectious degeneration \\
\hline & Bulgarian latent, Line pattern \\
\hline Vitis rupestris St. George & Infectious degeneration \\
\hline & Fleck, Rupestris stem pitting \\
\hline Vitis vinifera cv. Pinot noir & Leafroll, Infectious degeneration \\
\hline Vitis vinifera cv. Chardonnay & Yellow mottle, Line pattern \\
\hline & Infectious degeneration, \\
\hline V. berlandieri $\mathrm{x}$ V. riparia Kober $5 \mathrm{BB}$ & Kober stem grooving \\
\hline LN 33 (Couderc $1613 \mathrm{x}$ & $\begin{array}{l}\text { LN } \text { Stem grooving, Enation, } \\
\text { Corky bark }\end{array}$ \\
\hline V. riparia Gloire de Montpellier & Vein mosaic \\
\hline V. rupestris $\mathrm{x}$ V. berlandieri $110 \mathrm{R}$ & Vein necrosis \\
\hline
\end{tabular}


In vitro shoot tip cultures were established on halfstrenght Murashige-Skoog medium supplemented with 0.5 $\mathrm{mg} / \mathrm{l}$ benzyl-adenine from shoots started from hot water treated canes (Szegedi \& Civerolo 2011). Their sterile status was first tested by conventional microbiological techniques, by inoculating stem extracts onto appropriate bacterial and fungal media. DNA samples isolated from the sterile plants were further tested by PCR using the Agrobacterium vitis specific PGF/PGR primers (Szegedi \& Bottka 2002) and the universal fungal specific primers ITS4 and ITS5 (White et al. 1990). Samples for virus and phytoplasma detection were collected from the acclimatized in vitro materials from the greenhouse at July and September.

\section{Results and discussion}

The complicated quarantine and certification programs and the slow process of grape propagation via dormant cuttings are responsible for the shortage in certified grafted propagating material available on the market. In BácsKiskun county (Hungary) the sandy soils are not affected by phylloxera thus they allow the use of simple rapid propagation based on self-rooted plants. Unfortunately, nematodes still occur at high levels in these soils, thus the reestablishment of vineyards on such sites will require the use of nematode-resistant rootstocks. During the structural changes of the vine industry new varieties, clones, and rootstocks are introduced in this region. The demand for healthy propagating stocks from these new varieties and rootstocks will be increasing in the future. To produce pathogen-free plants a complex protocol was set up (Figure 2.) that allows the elimination and detection of the known systemic grapevine pathogens.

In the first year (winter of 2009/2010) dormant woody canes from 26 grapevine varieties were collected in Serbia and Hungary (Table 1.) and evaluated from sanitary wievpoints. The investigated Hungarian varieties proved to be true-to-type by RAPD and microsatellite marker analysis (data not shown). To eliminate pathogens and overwintering pests a two-step protocol was established.

First dormant woody canes were treated in hot water at 52 ${ }^{\circ} \mathrm{C}$ for $45 \mathrm{~min}$ to kill phytoplasmas, pests potential vectors and to reduce the population of bacterial endophytes. Agrobacterium cannot be completely killed by this treatment. However, the bacterium cannot migrate into the tips since vascular elements are lacking.

In the second step cuttings were shooted and in vitro shoot tip cultures were established using 1-2 mm shoot tips. The shoot tip culture (STC) is necessary to perform to completely eliminate bacterial (Szegedi \& Civerolo 2011) and fungal infections. Using this method we successfully established sterile cultures from 24 of the 26 varieties/clones. Neither bacterial nor fungal colonies were recovered from homogenized stem extracts on microbial or plant tissue culture media. These observations were further confirmed by PCR analysis of DNA samples prepared from 72 in vitro

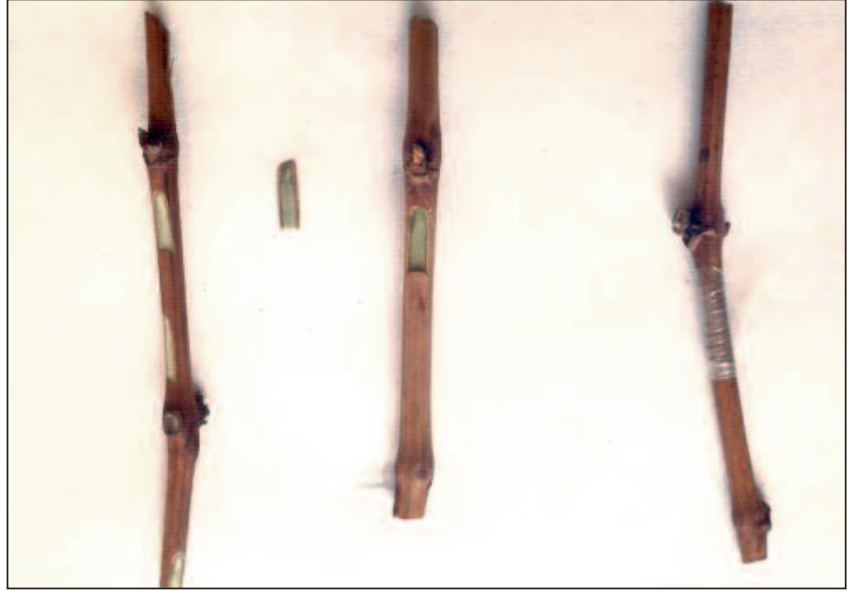

Figure 1. Woody indexing by chip-transmission

grapevine lines (three lines of each variety). Again, neither Agrobacterium vitis nor contaminating fungi were detected. Detection of viruses by multiplex RT-PCR (Gambino \& Gribaudo 2006, Gambino et al. 2008) and phytoplasmas (Stolbur phytoplasmas and Flavescence dorée, Kölber 2011) are in progress.

\begin{tabular}{|c|c|}
\hline Process of pathogen elimination & \\
\hline Selection of symptomless, true-to-type plants & \\
\hline Hot water treatment $\left(50^{\circ} \mathrm{C}, 60 \mathrm{~min}\right)$, shooting & 1. year \\
\hline Preliminary tests (ELISA, PCR, testing on indicators) & \\
\hline If positive-thermotherapy at $38^{\circ} \mathrm{C}$, & \\
\hline $\begin{array}{l}\text { Establishment of sterile, pathogen-free plants by in vitro meristem or } \\
\text { shoot tip cultures }\end{array}$ & \\
\hline In vitro micropropagation & \\
\hline Acclimatization of in vitro plants to the greenhouse & 2. year \\
\hline $\begin{array}{l}\text { Re-testing of plants to check their pathogen-free status (ELISA, PCR } \\
\text { and grafting onto indicator plants) }\end{array}$ & \\
\hline $\begin{array}{l}\text { Propagation of pathogen-free lines to establish prebasis, basis and } \\
\text { stock plantations }\end{array}$ & 3. year \\
\hline
\end{tabular}

Figure 2. Procedure to produce pathogen-free grapevine

If viruses are still present, the in vitro culture (STC) method can be combined with a second type of heat treatment that includes growth of acclimatized grapevine plants at $38^{\circ} \mathrm{C}$ for 3-4 months. Such treatment reduces the movement of virus particles in the plants, therefore a significant part of shoot tips becomes virus-free. This treatment is followed by establishment of in vitro meristematic cultures (MC) started from $<0.5 \mathrm{~mm}$ apical meristems. Due to the previous heat treatment, meristem culture is an effective tool for virus elimination since viruses frequently are not present in the shoot tip cells. However certain grapevine varieties are recalcitrant in this respect, thus plant regeneration from the apical meristems can be difficult. If virus-free stocks are available, shoot tip culture (STC) using a 1-2 $\mathrm{mm}$ apical part is usually sufficient to start 
the in vitro propagation for elimination of potential bacterial and fungal infections. Such cultures have been produced and acclimatized for greenhouse and field conditions in large scale (Figure 3.)

In the present program hot water (and if necessary, heat treatment), in vitro shoot tip culture supplemented with highly sensitive diagnostic techniques were combined with biological indexing on herbaceous and woody indicators to shorten the time reqired for establishment of pathogen-free stock materials. Generally, the selection of basic materials including visual selection and laboratory tests (ELISA and PCR-based techniques), heat therapy and in vitro STC culture, lasts for one year. After the first year the plantlets (in in vitro culture or already released to greenhouse) are free from bacterial and fungal pathogens, and are putatively virus-free.

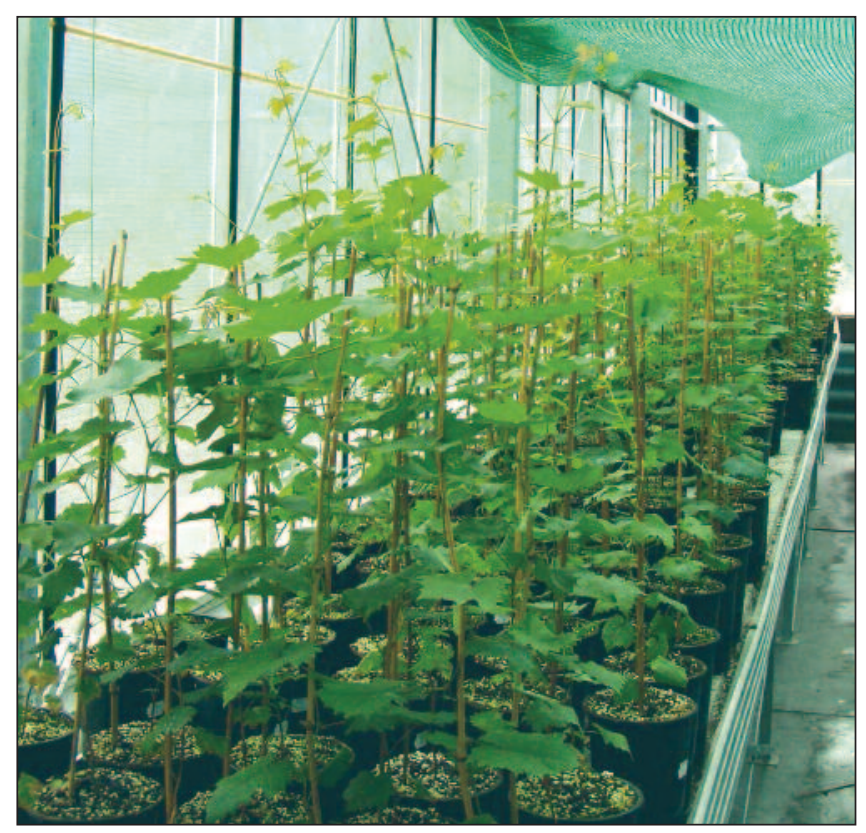

Figure 3. Acclimatized in vitro grapevine plants started from shoot tip cultures

Introduction of micrografting or green-grafting can further shorten the indexing time to 6 month or one year, respectively. The result of woody indexing is still the key point to get official certificate for virus-free prebasic stocks. The one year time for indexing is short enough to complete the whole procedure of producing pathogen-free materials in two years. As micropropagation of the in vitro grape plants is relatively easy, the propagation of the putatively virus-free plants can be accelerated further during the woody indexing time.

During our cross border project financed by the Serbian and Hungarian Governments and by the European Community (HU-SRB 0901/214/123 EU) we successfully established new pathogen-free stock materials of 26 varieties/clones (Table 1.). To this end in vitro shoot tip cultures were established from hot water treated material to eliminate pathogens and pests. Plant material was tested for grapevine pathogens with a complex detection system
(Figure 2.). Further improvement of this protocol applying green-grafting or micrografting for indexing on grapevine indicators can shorten the duration of the procedure from 4 years to two-three years.

\section{Acknowledgements}

Lázár, J., Szegedi, E., Varga, G. \& Hajdu, E. were supported by the HU-SRB 0901/214/123 EU project.

\section{References}

Bisztray, Gy. D., Korbuly, J., Halász, J., Oláh, R., Ruthner, Sz., Deák, T., Velich, I. \& Pedryc, A. (2003): Characterization of grape varieties and species by RAPD merkers. Proceedings of the Eight International Conference on Grape Genetics and Breeding, Kecskemét, Hungary 26-3, August 2002. Acta Horticulturae, 603: 601-604.

Bisztray, Gy. D., Deák, T., Eisenfeld, C., Pedryc, A., Balogh, J. \& Regner, F. (2005): Microsatellite based identification of grapevine cultivars traditional in Hungary and in the Carpathian Basin. International Journal of Horticultural Science, 11: 71-73.

Bodor, P., Varga, Zs., Deák, T., Pedryc, A. \& Bisztray, Gy. D. (2008): Old Hungarian grapevine cultivars and their relations characterized with microsatellite markers. International Journal of Horticultural Science, 14: 27-32.

Cseh, E., Darágó, Á., Takács, A. \& Gáborjányi, R. (2011): Survey on the occurrence of grapevine viruses in Hungary. Kertgazdaság, 43: 63-67.

Gambino, G. \& Gribaudo, I. (2006): Simultaneous detection of nine grapevine viruses by multiplex RT-PCR with coamplification of a plant RNA internal control. Phytopathology, 96: 1223-1229.

Gambino, G., Perrone, I. \& Gribaudo, I. (2008): A rapid and effective method of RNA extraction from different tissues of grapevine and other woody plants. Phytochemical Analysis 19, 520-525.

Kölber, M. (2011): Phytoplasma diseases of grapevine and the possible measures to control them. International Journal of Horticultural Science, 17 (3): 59-63.

Kölber, M., Lázár, J., Davis, R., Dally, E., Tőkés, G., Szendrey, G., Mikulás, J., Krizbai, L. \& Papp, E. (1997): Occurence of grapevine yellows disease in grapevine growing regions of Hungary. 12th Meeting of ICVG, Lisbon (Portugal), 28 Sept-2 Oct 1997. Extended Abstracts, 73-74.

Kuzmanovi, S., Dovas, C. J., Katis, N. I., Starivi, M., Tosic, M. \& Rajkovi, S. (2003): Contribution to the study of grapevine virus diseases in Serbia. Extended Abstracts 14th Meeting of ICVG, Locorotondo (Bari), Italy, 180-181.

Lázár, J. (1996): A szőlő vírusokkal kapcsolatos újabb hazai kutatások eredményei- Vírusbetegségek és mentes törzsültetvények létesítése. Doktori értekezés. Kertészeti és Élelmiszeripari Egyetem, Budapest

Lázár, J. \& Bisztray, Gy. D. (2011): Virus and virus-like diseases of grapevine in Hungary. International Journal of Horticultural Science, 17 (3): 59-63.

Lázár, J., Mikulás, J., Farkas, G. \& Kölber, M. (2002): Certification programme for production of virus free propagating 
material of grapevine and its results in Hungary. International Journal of Horticultural Sciences, 8: 39-43.

Lehoczky, J. \& Reichart, G. (1968): A szőlő védelme. Mezőgazdasági Könyvkiadó, Budapest, 41-58.

Lehoczky, J. \& Tasnády, Gy. (1971): Fertőző leromlás és a krómmozaik vírusos kórfolyamatának hatása a szőlőfélék terméshozamára és a bogyók cukortartalmára. Kísérletügyi Közlemények, 64: 49-64.

Lehoczky, J. \& Burgyán, J. (1986): A paradicsom fekete gyürüs vírus előfordulása szőlőben Magyarországon. Kertgazdaság, 13: 47-57.

Lehoczky, J., Luntz, O., Lázár, J., Kölber, M., Mikulás J. \& Farkas, G. (1992): Production of virus free grapevine propagating material in Hungary. 44th International Symposium of Crop Protection. Gent, Belgium, 333-339.

Mandić, B., Ivanović, Z., Susca, L., Bottalico, G., Starović, M., Jakšić, D., Kuzmanović, S., Ivanisević, D., Gavrilović, V., Korać, N., Diagoro, M. \& La Notte, P. (2009): Clonal selection and sanitary satus of local grapevine germplasm in Serbia. In: BoudonPadieu, E. (ed.) Extended abstracts of the 16th Meeting of ICVG, Dijon, France, 31 Aug-4 Sept 2009, 60-61.

Martelli, G. P., ed. (1992): Grapevine Viruses and Certification in EEC Countries: State of the Art. Quaderno No 3, Istituto Agronomico Mediterraneo (I.A.M.), Bari, Italy

Martelli, G. P. (2009): Grapevine virology highlights. In: BoudonPadieu, E. (ed.) Extended abstracts of the 16th Meeting of ICVG, Dijon, France, 31 Aug-4 Sept 2009, 15-23.

Martelli, G. P. \& Boudon-Padieu, E. (2006): Directory of infectious diseases of grapevines and viruses and virus-like diseaes of the grapevine, Bibliographic report 1998-2004. Options Méditerranéennes, Serie B: Studies and Research, 55: 279.

Neszmélyi, K., Bach, I. \& Szőnyegi, S. (1996): The certification scheme of propagating materials in Hungary. National Institute for Agricultural Quality Control, Plant Health and Soil Conservation Station Coordination Unit, Budapest, 1996

OEEP/EPPO (2008): Certification scheme: Pathogen-tested material of grapevine varieties and rootstocks, PM 4/8(2), Bulletin OEPP/EPPO Bulletin, 38: 422-429.

Starovi, M., Kuzmanovi, S., Ivanovi, Z., Alaksi, G. \& Stojanovi, S. (2007): Viruses of the local grapevine cultivars in Serbia. 5th Balkan Congress for Microbiology, 24-27. October, 2007, Budva. Abstracts book, 132.

Szegedi, E. \& Bottka, S. (2002): Detection of Agrobacterium vitis by polymerase chain reaction in grapevine bleeding sap after isolation on a semiselective medium. Vitis. 41: 37-42.

Szegedi, E. \& Civerolo, E. L. (2011): Bacterial diseases of grapevine. International Journal of Horticultural Science, 17 (3): 59-63.

Varga, Zs., Bisztray, Gy. D., Bodor, P. \& Lörincz, A. (2008): Régi tokaj-hegyaljai fajták értékelése mikroszatellit markerekkel. Kertgazdaság. 40, 47-52.

White, T. J., Bruns, T., Lee, S. \& Taylor, J. W. (1990): Amplification and direct sequencing of fungal ribosomal RNA genes for phylogenetics. Pp. 315-322 In: PCR Protocols: A Guide to Methods and Applications, eds. Innis, M. A., D. H. Gelfand, J. J. Sninsky, \& T. J. White. Academic Press, Inc., New York 